folk/ed. Derg, 2020; 26(3):527-544

DOI: $10.22559 /$ folklor.1325

\title{
Corona ve Paul Celan Ya da Aşk ve Pandemi
}

\author{
Corona and Paul Celan or Love And Pandemic
}

\section{Funda Kızıler Emer*}

\section{Öz}

2020 yılı tarih sayfalarında daha şimdiden, Corona virüs salgınının dünyanın her yerinde milyonlarca can aldığı bir pandemi yılı olarak yer edinmiştir. Bu yıl aynı zamanda savaş sonrası Avusturya liriğinin tanınmış şairlerinden biri olan Paul Celan'ın (1920-1970) ölümünün de 50. y1lına denk gelir. İlginçtir ki Celan, bundan yetmiş iki yıl önce yazdığı bir şiirine "Corona" adını vermiştir. 1948 yılı dünya tarihinde II. Dünya Savaşı'nın bitiminden üç yıl sonrasına karşılık gelir. Celan'ın kişisel tarihindeyse, ebeveynlerini kurban verdiği Nazi ölüm kampından kurtulduktan sonra, Czernowitz'e, Bükreş'e ve ardından Viyana'ya göç ettiği zorlu yıllara rastlar. Celan'ın burada Viyana yazın çevresinde kurduğu dostluklar, özellikle de Avusturyalı şair Ingeborg Bachmann'la (1926-1973) tanışması yaşamında bir dönüm noktası oluşturur. İki büyük şair tutkulu bir aşk yaşar. Celan'ın bu şiiri, 1948'de yaşanan bu aşktan izler taşır. Bu çalışmanın temel amacı; Celan'ın bu şiirini analiz etmek ve aynı zamanda günümüzde milyonlarca insanın ölümüne neden olan pandemik virüsün adı olarak tanınan Corona ile Celan'ın aynı başlıklı şiiri arasında bir ilişki olup olmadığını araştırmaktır. Bu şekilde hem 2020'de ölümünün 50. yılına girdiğimiz usta şairin şiirlerine, hem de tüm insanlığı tehdit eden Corona virüs salgınına dikkat çekmek hedeflenmiştir. Bu çalışmada "yakın okuma" yöntemini, tarihsel pozitivist, biyografik eleştiri yöntemlerini ve yorumbilgisini içeren eklektik bir yöntem kullanılmıştır.

Anahtar sözcükler: Celan, Avusturya yazını, corona, aşk, pandemi, holocaust

Geliş tarihi (Received): 23.04.2020 - Kabul tarihi (Accepted): 25.06.2020

* Doç.Dr., Sakarya Üni. Fen-Edb. Fak. Alman Dili ve Edb. Bölümü. fkiziler@yahoo.de. ORCID ID 0000-00032204-3063 


\begin{abstract}
The year 2020 has already taken place in history pages as a year of pandemic in which the coronavirus outbreak has taken millions of lives all over the world. This year also coincides with the $50^{\text {th }}$ anniversary of the death of Paul Celan (19201970), one of the well-known poets of the post-war Austrian lyric. Interestingly, Celan named his poem Corona, which he wrote seventy-two years ago. The year 1948 corresponds to three years after the end of the Second World War in world history. In Celan's personal history these years coincide with tough times, when he emigrated to Czernowitz, Bucharest and then Vienna after surviving the Nazi death camp where his parents were sacrificed. The friendships that Celan built here with the writers around the literature in Vienna, especially meeting the Austrian poet Ingeborg Bachmann (1926-1973), constitute a turning point in his life. Two great poets experience passionate love. This poem of Celan carries traces of this stormy love in 1948. The main purpose of this study is to analyze this poem and also to investigate whether there is a relationship between Corona and Celan's poem with the same title, which is known as the name of the pandemic virus that has killed millions of people today. In this way, it is aimed to draw attention to both the poetry of the master poet, who entered the $50^{\text {th }}$ year of his death in 2020 , and the epidemic of the Corona virus that threatened all humanity. In this study, an eclectic method including "close reading", historical positivist, biographical critism and hermeneutic methods has been used.
\end{abstract}

Keywords: Celan, Austrian literature, Corona, love, pandemic, holocaust

\title{
Extended summary
}

2020 is already in the memory and history of all mankind as a frightening pandemic year in which the Corona virus epidemic has taken millions of lives all over the world and has undergone a radical change in every aspect of life. The World Health Organization (WHO) has defined the new type of Corona virus outbreak as "endemic" and then "pandemic". "Epidemic" is a concept that is used to describe any event that cannot be controlled in general terms, which means that a disease spreads in a certain area- among a certain community or group and within a certain population range. "Pandemic" means that a disease transcends regions and groups and affects a country or the world as it is today. However, this current pandemic also coincides with the 50th anniversary of the death of one of the most authoritative poets of the post-war Austrian literature, Paul Celan (1920-1970). Interestingly, Paul Celan named a poem he wrote about seventy-two years ago. Paul Celan wrote this poem "Corona" in 1948, but the poem was published only in 1952, in "Mohn und Gedächtnis", a poetry book that he also named with a string. The year 1948 corresponds to three years after the end of World War (1939-1945) in the world history. In Paul Celan's personal history, after surviving the Nazi death camp where his parents were victimized, it coincides with the difficult and 
tough years when he first migrated to his hometown Czernowitz, then to Bucharest and then to Vienna. On the other hand, Celan's friendships with writers and poets around the summer of Vienna, especially the Austrian poet Ingeborg Bachmann (1926-1973), is a turning point in both poetry and private life. The two great poets, Celan and Bachmann experience passionate love in Vienna, which also has a formative effect on their poetry. Here, Celan's poem "Corona" carries traces of the stormy love that he had with the Austrian poet Ingeborg Bachmann, whom he met in May 1948. But the love of a prisoner of war, whose parents were killed in the Nazi concentration camp, with the daughter of a Nazi officer, was doomed to unhappiness from the beginning.

Paul Celan survived the concentration camp, where he was held captive for eighteen months, but could never escape the intense persecution and horror he experienced, especially the deep pain of sacrificing his parents to Nazi Germany. It was not his body but his soul that was infected by this black virus detaching him from life he had never been able to hold on and causing his suicide by jumping the River Seine. In other words, Celan is also the victim of another virus that leaves up to six million bodies. He is one of the victims of racist and fascist Nazism, which took millions of lives just like the plague. Ingeborg Bachmann, an Austrian poet who was the daughter of a Nazi officer and who had a great love in Vienna in the spring of 1948, committed suicide (in a fire in a night when she took sleeping pills at her home in Rome) like him three years after Celan had-passed away. This poem-witnesses the first moments when the passionate, tragic and sad love that 22-year-old Bachmann and 27-year-old Celan had. As the top title of "Corona and Paul Celan" shows, the main aim of this study is to analyze Paul Celan's poem "Corona" in a way that reveals the expansions of this interesting title in the deep semantic plane. In order to clarify why and what semantics they may have, outside the text; This antagonistic feature in the history of the formation of the text by turning to Paul Celan's personal history / life story; We also included tragic and hateful love (amor fou) in our analysis. The word "love" in the subtitle of the study, "Love and pandemic", comes from here. The first thing that comes to mind when the word "pandemic" is mentioned in the world history is undoubtedly the plague epidemic that killed millions of people in the Middle Ages and the most remarkable reflections of this epidemic in the world literature are the "Decameron" (1353) by the Italian writer Giovanni Boccacio and the the "Plague" ("La Peste", 1947) by the French writer Albert Camus. ("Salgın”, a story by Reşat Nuri Güntekin can be given as an example from the Turkish literature). When it is said 'love and epidemic disease', Gabriel Garcia Marquez's "Love in Cholera Days" ("El amor en los tiempos del cólera", 1985), Arthur Schnitzler's "Death" ("Das Sterben”, 1895) and Thomas Mann's "Death in Venice" ("Der Tod in Venedig", 1912) is one of the first examples. As the subtitle of this study suggests, there is also a relationship between Corona (the name in the medical literature and Covid-19), which we all are familiar with and the poetry of Celan, which we all are familiar with, as the name of a very dangerous pandemic virus that causes the death of millions of people today. This relation is investigated and questioned in the study. Therefore, the secondary aim of this study is to draw attention to the poetry of the master poet Paul Celan, whose $50^{\text {th }}$ anniversary of death is commemorated in 2020, and the Corona virus 
outbreak that threatens all humanity. The method used in this study is 'eclectic' which includes both the 'close reading' (Todorov) method that is left in the text, the biographical criticism, the historical and positive (positivist) methods of criticism out of the text, and the hermeneutics (hermeneutics) using the in-text (werkimmanent) and non-text (werkextern) data.

\section{Giriş}

2020 yılı insanlık olarak hepimizin belleğinde ve tarih sayfalarında, dünya çapında (yeni tip) Corona virüs salgınının milyonlarca can aldığı, yaşamlarımızı her açıdan kökten bir değişime uğrattığı korku verici bir yıl olarak yer edindi. 2019'un Aralık ayında Çin'in Hubei eyaletinin Wuhan kentinde görülen çok sayıdaki “pnömoni” vakasının nedeni, 12.01.2020'de Dünya Sağlık Örgütü (DSÖ) tarafından yeni tip koronavirüs olarak açıklandı. SARS-CoV-2 olarak adlandırılan bu Corona virüs salgını önce "endemi”, ardından "pandemi” olarak tanımland.. "Epidemi", genel anlamda denetlenip kontrol altına alınamayan herhangi bir olayı anlatmada kullanılan bir kavram olup, tıp literatüründe bir hastalığın belli bir alanda, belli bir toplum ya da grup arasında ve belli bir popülasyon aralığında yaygınlaşması anlamına gelir. "(E)ski Yunanca'da pan: tüm + demos: insanlar" anlamına gelen "pandemi” ise, bir hastalığın, yeni bir virüsün bölgeleri, ülkeleri ve hatta kıtaları aşarak hızlıca ve kolayca çok geniş bir alana yayılmasını, günümüzde olduğu gibi tüm dünyayı etkisi altına alan bir salgına dönüşmesini ifade eder (Şeker vd., 2020, s. 15-20; tr.euronews.com, 2020).

Ancak içinde bulunduğumuz bu yıl aynı zamanda, savaş sonrası Avusturya liriğinin (Nachkriegsliteratur) dünya çapında tanınmış en yetkin kalemlerinden biri olan Paul Celan'ın (1920-1970) ölümünün de 50. yılına tekabül etmektedir. İlginçtir ki; o Celan da, ardında yaklaşık altı milyona varan ceset bırakan başka bir 'virüs'ün kurbanıdır; Rönesans'ın ve Aydınlanma'nın çocuklarını kitleler halinde "Heil Heil!", "Viva Viva!” haykırışlarıyla toplu katliam ve savaşlara koşturan (Kızıler, 2006, s. 93 vd.), Camus'un La Peste'de (1947) "kara veba" (Camus, 1985) alegorisiyle sunduğu, tıpkı veba gibi milyonlarca can alan ırkçı ve faşist Nazizmin kurbanlarından biridir. Celan iki yıla yakın bir süre esir kaldığı toplama kampından kurtulmuş, ama yaşadığı anlatılmaz zulmün ve dehşetin, hele ki ebeveynlerini savaşa kurban vermenin derin acısından asla kurtulamamıştır. En çok bu 'kara virüs'ün ruhuna dövmelediği acıdandır ki, asla tutunamadığı yaşamdan doğal bir ölümle değil, Seine Irmağı'na atlayarak ayrılmıştır.

Yine ilginç bir rastlantıdır ki, Paul Celan 1948 yılında "Corona” başlığını verdiği bir şiir kaleme almıştır. 1948 yılı dünya tarihinde II. Dünya Savaşı’nın (1939-1945) bittiği tarihten üç yıl sonrasına karşılık gelir. Paul Celan'ın kişisel tarihindeyse, anne-babasını kurban verdiği Nazi ölüm kampından sağ olarak kurtulduktan sonra, önce memleketi Czernowitz’e, ardından Bükreş'e ve sonra da Viyana'ya göç ettiği zorlu ve çetin yıllara denk gelir. Öte yandan Celan'ın burada, Viyana yazın çevresindeki yazarlarla ve şairlerle kurduğu dostluklar, özellikle de Avusturyalı şair Ingeborg Bachmann'la (1926-1973) tanışması hem şairlik yaşamında hem de özel yaşamında tam anlamıyla bir dönüm noktası oluşturur. İki büyük şair Celan ve Bachmann, poetikalarına da biçimlendirici bir etki yapan tutkulu bir aşk yaşar. İşte Celan'ın “Corona” adlı bu şiiri, 1948 yılının Mayıs ayında tanıştığı Bachmann’la yaşadığı bu aşktan izler taşır (1). 
“Corona ve Paul Celan” şeklindeki üst başlığının ortaya koyduğu gibi, bu çalışmanın temel amacı; Celan'ın “Corona” adlı bu şiirini, özellikle bu başlığın derin düzlemdeki anlamını ortaya çıkaracak biçimde analiz etmektir. Sözlük anlamı itibarıyla son derece kapalı olan bu başlığın şiire niçin konulduğunu ve semantik açıdan neye karşılık geldiğini aydınlatmak için, Celan'ın kişisel tarihine / yaşamöyküsüne yönelerek, metnin oluşum tarihinde yaşanan bu antagonistik nitelikteki aşkı da analizimize eklemledik. Çalışmanın "Ya da Aşk ve Pandemi” şeklindeki alt başlığındaki "aşk" da buradan kaynaklanmaktadır. Dünya tarihinde "pandemi” denilince ilk akla gelen hiç kuşkusuz, yine Çin'den çıkıp tüm dünyayı saran, "1347 yılında Avrupa nüfusunun yaklaşık üçte birinin ölümüne” (Şeker vd., 2020, s. 21) yol açan vebadır ve bu salgının dünya yazınına yansımaları arasından da en dikkat çekici olanları, İtalyan yazar Giovanni Boccacio'nun (1313-1375) Decameron'u ([1353], 2018) ve Fransiz yazar Albert Camus'un (1913-1960) Veba'sıdır. Türkçe yazından da Reşat Nuri Güntekin'in (1889-1956) "Salgın” (2010) adlı öyküsü buna örnek verilebilir. Aşk ve hastalık denilince de Kolombiyalı yazar Gabriel G. Marquez'in (1927-2014) Kolera Günlerinde Aşk'1 (1985), Avusturyalı yazar Arthur Schnitzler'in (1862-1931) Das Sterben'i ([1895], 1992) ve Alman yazar Thomas Mann'1n (1875-1955) Der Tod in Venedig'i ([1912], 1993) akla gelebilecek ilk örneklerdendir. Çalışmanın alt başlığındaki “pandemi”nin imlediği, burada aynı zamanda günümüzde milyonlarca insanın ölümüne neden olan çok tehlikeli bir pandemik virüsün adı olarak tanınan Corona (tıp literatüründeki adıyla Covid-19) ile Celan'ın aynı başlığı taşıyan bu şiiri arasında bir ilişki olup olmadığı araştırılıp sorgulanmıştır. Dolayısıyla bu çalışmanın tali amacı da şudur: Tüm bu ilginç rastlantılardan yola çıkarak, hem 2020 yılında ölümünün 50. yılına girdiğimiz usta şair Paul Celan'ın şiirlerine, hem de tüm insanlığı tehdit eden Corona virüs salgınına dikkat çekmektir.

Çalışmada seçilen konuya uygun olarak, hem metnin içinde kalan "yakın okuma" (Todorov, 2001: 8) hem metnin dişına çıkan biyografik eleştiriyle (Moran, 1994, s. 117-134) tarihsel pozitivist eleştiri yöntemlerini (Maren-Grisebach, 1972, s. 10-22), hem de metnin içi ve metin dışı düzlemleri sentezleyerek kullanan yorumbilgisini (hermeneutik) (Toprak, 2016) içeren 'eklektik bir yöntem' kullanılmıştır.

\section{I-Paul Celan'a ve poetikasına dair}

23.11.1920'de, Czernowitz'de, Almanca konuşan Musevi bir ailenin oğlu olarak dünyaya gelen Paul (Antschel) Celan, 30.04.1970’te Paris’te intihar etmiştir. 1942'de çok sevdiği ailesini Nazi toplama kampında (KZ) yitirmesinin acısı, onu bir ömür boyu bırakmamıştır. Romanistik, Anglistik ve Germanistik okumuş, Bükreş, Viyana ve Paris kentlerinde yaşayıp farklı üniversitelerde iyi bir kariyer yapmış, 1952'de evlenip çocuk sahibi olmuş, yani yaşadığ 1 travmaya rağmen yaşama tutunmaya çalışmış, ancak başaramamıştır.

Celan Nazi ölüm kampından kurtulduktan sonra Czernowitz’e geri döner, sonra Bükreş’e ve ardından da Viyana'ya göç eder. Viyana yazın çevresinde kurduğu dostluklar, özellikle de şair Ingeborg Bachmann'la (1926-1973) tanışması yaşamında bir dönüm noktası oluşturur. İki şair poetikalarına da biçimlendirici bir etki yapan tutkulu bir aşk yaşar (Sparr, 1997, s. 176-188). Ancak bir süre sonra Celan, Viyana'dan ve Bachmann'dan ayrılarak Paris'e yer- 
leşir. Akademisyenliğin yanısıra çevirmenlik, editörlük ve serbest yazarlık yapar. 1950'de Paris'teki Germanistik öğrenimini tamamlar, 1952'de Giséle de Lestrange adlı bir sanatçıyla evlenir, 1955'te Fransız vatandaşlığına kabul edilir.

Kendisinin de on sekiz ay esir edildiği toplama kampındaki anlatılmaz dehşetin ve ebeveynlerinin öldürülmesinin - özellikle de çok sevdiği annesinin bir Nazi subayı tarafından silahla vurularak öldürülmesini şiirlerinde de motif haline getirmiştir - acısını asla atlatamayan Celan, 1970'te - muhtemelen 20 ila 30 Nisan arası bir tarihte - Seine nehrine atlayarak intihar etmiştir (Hiebel, 2006, s. 255; Sparr, 2012, s. 104-105; Sparr, 2020, s. 26-30).

Müzikalitesi ve artistik yönüyle dikkat çeken Celan şiirleri otobiyografik bir nitelik taşır. Celan'ın poetikasında travmatik yaşam deneyimleri belirleyici bir rol oynar, ama onun başta “Todesfuge” (Ölüm Fügü) olmak üzere 20. Yüzyıl dünya şiirine damgasını vuran şiirlerinin önemi; kişisel tarihinin çağın tarihiyle keskin biçimde kesişmesinden kaynaklanır. Onun şiirleri, kendi yaşamıyla birlikte, daha doğrusu onu aşarak; 20. Yüzyıl tarihinin en önemli paradigması olan - gaz odaları ve krematoryum firınlarıyla - "toplama kampı" dehşeti, II. Dünya Savaşı sürecinde Nazi Almanya'sında gerçekleştirilen sistematik Musevi (Sinti ve Romanlar da dahildir bu gruba) soykırımı, yani 'Holocaust' ana temasıyla çağa da tanıklık eder (Felstiner, 2010, s. 28-45).

Yeni Romantizm, dişavurumculuk, Fransız simgeciliği ve gerçeküstücülüğünden etkilenen Celan'ın, ezoterik-mistik-avangart karışımı şifreli bir dille, kapalı ve karanlık imgelerle yoğrulmuş lirik evreninde Kitab-1 Mukaddes'ten, özellikle Tora'dan, Kabbala ve Zohar mistisizmlerinden önemli izler bulunur. Celan'ın başlıca şiir kitapları şunlardır: Der Sand aus den Urnen (1948), Mohn und Gedächtnis (1952), Von Schwelle zu Schwelle (1955), Sprachgitter (1959), Die Niemandsrose (1963), Atemwende (1967), Fadensonnen (1968), Lichtzwang (1970), Schneepart (1971) ve Zeitgehöft (1976). Şairin aldığı sayısız yazın ödülü içinde de en önemlisi (1960) Büchner Yazın Ödülü'dür (Hoffmann\&Rösch, 1980, s. 380381; Sparr, 2012, s. 104-107).

\section{II- Paul Celan'ın "Corona" adlı şiiri}

Paul Celan “Corona” adlı bu şiirini 1948 yılında yazmış, ama şiir ancak 1952'de, aynı zamanda bir dizesiyle adını da verdiği şiir kitabı olan Mohn und Gedächtnis'te yayımlanmıştır. Şiirin Almanca orjinali şöyledir:

\section{Corona}

Aus der Hand frißt der Herbst mir sein Blatt: wir sind Freunde.

Wir schälen die Zeit aus den Nüssen und lehren sie gehn:

die Zeit kehrt zurück in die Schale.

Im Spiegel ist Sonntag, im Traum wird geschlafen, der Mund redet wahr. 
Mein Aug steigt hinab zum Geschlecht der Geliebten:

wir sehen uns an,

wir sagen uns Dunkles,

wir lieben einander wie Mohn und Gedächtnis,

wir schlafen wie Wein in den Muscheln,

wie das Meer im Blutstrahl des Mondes.

Wir stehen umschlungen im Fenster, sie sehen uns zu von der Straße:

es ist Zeit, daß man weiß!

Es ist Zeit, daß der Stein sich zu blühen bequemt,

daß der Unrast ein Herz schlägt.

Es ist Zeit, daß es Zeit wird.

Es ist Zeit.

(Celan, 1983, s. 37).

Serbest uyakla yazılmış olan "Corona" adlı bu şiir, toplamda on sekiz dizeden oluşur. Şiirin dördüncü kıtasının ilk dizesindeki “cadde, sokak” anlamına gelen "Straße:” sözcüğüne dek semantik açıdan kesintisiz bir akış içinde olduğu, ancak bu noktada durumun değiştiği gözlenir. Şöyle ki: "Wir stehen umschlungen im Fenster, sie sehen uns zu von der/ Straße:" (Celan, 1983, s. 37) - Türkçesi (2) şöyledir: "Sarmaşdolaş duruyoruz pencerede, seyrediyorlar/ bizi sokaktan:" (Celan, 2005, s. 129) - şeklindeki bu 13. dize, metni hem uzamsal olarak - ev olduğu varsayılabilecek olan - kapalı ve mahrem bir 'iç-uzam' ve toplumsal / gündelik yaşamın egemen olduğu kamuya açık bir 'dış-uzam' olarak ikiye böler, hem de şiirdeki figürleri "biz” ve "ötekiler” şeklinde iki ulama ayırır. Ancak şiir aslında imgesel bir doğa betimiyle açılır:

"Sonbahar, avucumdan yemekte yaprağını: biz dostuz.

Badem kabuklarından soyup zamanı, ona gitmeyi

öğretiyoruz:

Zaman, kabuğuna dönüyor” (Celan, 1998, s. 58).

Şiirin iç zamanı bir “sonbahar” vaktidir. Sonbahar doğanın ışıltısını, renklerini, canlılığını yavaş yavaş yitirmeye, adeta ölüme hazırlandığı bir mevsim olarak hüznü, melankoliyi, en çok da ölümü temsil eder. O halde "biz dostuz" ifadesi lirik ben'in, melankoliyi alt edebilme gücünü ya da insanın en temel varoluşsal sorunu olan ölümle kurduğu ilişkinin niteliğini imler (3).

Öte yandan burada aynı zamanda lirik ben'in sonbahar mevsimini kişileştirerek (Personifikation) - Almancada hayvanların yemek yemesi anlamında kullanılan "fressen" fiilinin imlediği gibi - adeta 'evcil bir hayvana' çevirdiği dikkati çeker. Şiirin 2. ve 3. dizelerinde de “zaman” kavramının kişileştirildiği ve - adeta sonbahar gibi evcilleştirilerek -eğitildiği gözlemlenir: “[...], ona gitmeyi/ öğretiyoruz: / Zaman, kabuğuna dönüyor (Celan, 1998, s. 58). 
Celan'ın kişileştirme sanatını kullandığı "sonbahar" ve "zaman” kavramları semantik açıdan birbiriyle doğrudan ilişkili olup, zaman sonbaharı kapsayan daha üst bir kavram konumundadır. Şiirin ilk kıtasında elde edilen bu veriler, şiirde zaman kavramına, daha doğrusu içinde yaşanılan çağa ve statüko'ya karşı eleştirel bir tutumun varlığını ortaya koyar (4).

Metin dışındaki zamansal boyuta baktığımızda, şiirin kaleme alındığı 1948 yılı, savaşın bitiminden üç yıl sonrasına karşılık gelir. Ancak Sıcak Savaş yerini daha 1946’larda Soğuk Savaş dalgasına bırakmıştır. Dolayısıyla dışarıdaki dünya hala ölümcül bir tehlike saçan savaş virüsünden kurtulamamıştır. Ki şair bunu derin anlam düzleminde tıpkı sonbahar gibi evcilleştirilip eğitilen bir canlı metaforuyla sunar okuruna. Lirik ben'in zaman'a karşı bu ehlileştirici müdahalesi, diğer dizelerde daha çok belirginleşir:

"Aynadan yansimakta Pazar, düşlerde uyunuyor, ağızlar doğruyu söylemekte” (Celan, 1998, s. 58).

Yansıtma özelliğinden dolayı içinde yaşanılan uzamı 'burası' ve 'orası', özdeksel gerçekliği 'aslı' ve 'benzeri' şeklinde ikiye bölen bir nesne oluşuyla dinsel, felsefel ve yazınsal açıdan çok geniş bir simgesel art alanı olan aynanın (Emer Kızıler, 2014, s. 278) buradaki kullanımı, metaforik düzlemde görünen'den görünmeyen'e, fiziksel dünyadan fizik-ötesi boyuta kapı açarak gerçekliği sorunsallaştırma işlevi görür. Pazar günüyse, haftanın 7. günüdür. Yedi, kadim inanışlardan bu yana dünyanın nerdeyse tüm kültürlerinde kendisine kutsallık atfedilen "(b)ilgeliğin (s)ütunları(na)" yerleştirilen bir rakamdır (Schimmel, 1998, s. 140168). Eski Ahit'in Yaratılış kısmında, yeryüzünü altı günde yaratan Tanrı'nın dinlendiği gün olarak geçtiği için (Yaratılış, 2: 2-3), Musevi-Hıristiyan geleneğinde 'kutsal' sayılır. O halde Celan'ın, - "Im Spiegel ist Sonntag” (Celan, 1983, s. 37) şeklindeki bu dizede aliterasyon (Alliteration) sanatını kullanarak - yan yana getirdiği "ayna" ve "Pazar" sözcükleriyle dünyadaki - evcilleştirilmesi / eğitilmesi gereken - yabanlığa karşı kutsal'1 çağırdığg savlanabilir. Ardından da birbirine zıt gibi görünen "düş" ("Traum”) ve "hakikat" (“wahr”) kavramları açığa çıkar ki bu da şiirde, gerçek dünyada yitirilip ancak uykularda ve düşlerde - iç dünyada - açılan bir hakikat' in söz konusu edildiğini imler. ( $O$ halde dış-uzamda aynı zamanda hakikat' in karşıtı bir düzen hüküm sürmektedir).

Şiirin metaforik bir doğa betiminden, ayna ve düşlerle insanın iç dünyasına / hakikatin alanına yönelen ilk iki kıtasından sonra gelen kıtası, yani yedi ila on ikinci dizeler arasında kalan kısım, bu "biz" ("wir") denilen figürlerin aslında kimler olup, aralarında ne türden bir ilişki olduğunu daha belirgin biçimde anlatmaya odaklanır:

“Gözüm aşağı indi cinsine sevdiğimin:

Baktık birbirimize,

karanlığı söyledik birbirimize, sevdik birbirimizi afyon ve hafıza gibi, uyuduk midyelerin içinde şarap gibi, deniz gibi ayın kan 1şınında" (Celan, 2005, s. 129). 
Burada, şiirin orijinalinde konuşan lirik ben'in "biz" olduğu yanındaki diğer kişinin "Mein Aug steigt hinab zum Geschlecht der Geliebten:" (Celan, 1983, s. 37) hem bir kadın figür - tamlamadaki sözcüğün yalın hali olan die "Geliebte" bunu imler - olduğu, hem de eril lirik ben'le bu kadın figür arasındaki ilişkinin bir 'aşk' ilişkisi olduğu belirgin biçimde açığa çıkar. Yukarıdaki dizelerden bu figürlerin; birbirine bakmak, bir şeyler söyleyip anlatmak, birbirini sevmek/ sevişmek ve uyumak eylemlerini birlikte yaparak "biz" oldukları, kabaca mahrem bir alana kapanmış aşıklar oldukları okunur.

Ancak bu aşk, sıradan bir aşk değildir: Bu aşık çift, birbirine "karanlık" 1 söyleyip anlatmaktadır, yani "karanlık" ("Dunkles") hakkında kafa yormaktadırlar, birbirleriyle bu konuyu tartışmaktadırlar. Bu veri; iki aşık arasındaki ilişkinin yalnız tensel bir nitelik taşımayıp, düşünsel açıdan da güçlü olduğunu ortaya çıkarır. Bu dizeden aynı zamanda bu figürlerin entelektüel kişiler olup ikisinin de sözcüklerle aralarının iyi olduğu çıkarsanmaktadır. Buradaki "karanlık" metaforu herşeyden önce aşıkların kendilerini yalıttığı dış-uzamdaki olumsuzluğu, daha doğrusu dünyadaki kötülük sorununu imler ki, zaman'ın ehlileştirilmesi gereken yaban bir varlık gibi betimlenmesiyle de örtüşür bu.

Bu âşıklar, birbirlerini “afyon ve hafıza gibi” ("Mohn und Gedächtnis”) sevmektedirler. Aynı zamanda şiir kitabına adını veren bu benzetme şiirin en can alıcı noktasıdır. Afyon bitkisi yazın dünyasında genellikle unutmanın metaforudur, bellekse tam tersine anımsamanın. Afyon beyni uyuşturup unutmaya yararken, “(g)eçmişteki deneyimleri, tecrübe ve yaşantıları anımsayabilme yetisi" olan hafıza/ bellek, "(d)eney ya da tecrübeleri anımsama(ya), zihinde canlandırma(ya) ve geçmişi şimdide koruma(ya)” (Cevizci, 1999, s. 111) hizmet eder. O halde bu çiftin antagonistik nitelikli aşkında hem karanlık'ın imlediği kötülüğü unutmak hem de onu tekrar anımsayıp (5) onunla başa çıkabilmek, onu alt edebilmek şeklinde açıklanabilecek bir tür iç gerilim söz konusudur. Peki dünyadaki bu "karanlık"la nasıl başa çıkılabilecektir sorusuna da "Badem kabuklarından soyup zamanı, ona gitmeyi / öğretiyoruz:" (Celan, 1998, s. 58) dizesinin imlediği gibi, “Aşk’la! eğiterek” yanıtını verir şiir adeta.

Daha sonra gelen "uyuduk midyelerin içinde şarap gibi, / deniz gibi ayın kan 1şınında" (Celan, 2005, s. 129) dizeleriyse; aşk içeceği olan "şarap" ve aşkın / tutkunun - ve ölümün rengi olan kırmızıyı çağrıştıran "kan 1şını” metaforları başta olmak üzere, "midye”, "deniz” ve "ay" gibi bileşenlerle tutkulu bir aşkın poetik tablosunu çizer âdeta. Nitekim ünlü din tarihçisi Mircea Eliade (1907-1986) "midye", “deniz" ve "ay" 1n, "tarih öncesinden modern zamanlara kadar dünyanın her yerinde rastla(nan)" ortak bir simgesel bir art alana sahip olduğunu belirtir:

İstiridyeler, deniz kabukları, sümüklü böcek, inci suya ilişkin kozmolojilerde olduğu kadar, cinsel simgecilik alanında da dayanışma içindedirler. Nitekim bunların hepsi de Sularda, Ayda ve Kadında yoğunlaşmış olan kutsal güçlere ortak olmaktadırlar; bunlar ayrıca, çeşitli nedenlerden ötürü bu güçlerin amblemleridir: deniz kabukları ile kadın üreme organları arasındaki benzerlik; istiridyeleri, suları ve ayı birleştiren ilişkiler; nihayet istiridyenin içinde oluşan incinin jinekolojik ve ambriyolojik simgeciliği. İstiridyelerin ve deniz kabuklarının sihirsel yeteneklerine olan inanca, tarih öncesinden modern zamanlara kadar dünyanın her yerinde rastlanmaktadır (1992, s. 143). 
O halde insanlığın kadim zamanlarından bu yana simgesel düzlemde cinselliği ifade eden "midye", "deniz" ve "ay" ın bu dizelerde art arda kullanılması, şiirdeki iki aşığın düşünsel açıdan olduğu gibi, tensel açıdan da çok yoğun, oldukça tutkulu bir ilişkisi olduğunu açığa çıkarır. Dişiliği, dişi cinsel organını, cinselliği simgeleyen (6) tüm bu motifler, şiirin "Gözüm aşağı indi cinsine sevdiğimin:” şeklindeki 7. dizesiyle de semantik bir bütünsellik oluşturur.

Başlangıçta da belirttiğimiz gibi; şiirin 13. dizesi, şiiri özel / mahrem ve kamusal alan olmak üzere iki farklı uzama, figürleri de "biz" ("wir") ve "onlar" (“sie") olmak üzere iki farklı gruba ayırır: Aşıklar pencerenin kenarında "(s)armaşdolaş” durmakta, toplumu temsil eden "ötekiler" de onları "sokaktan" (Celan, 2005, s. 129) izlemektedir. "Pencere" motifinin de şöyle ikili bir işlevi vardır: hem mahrem alanda bulunan iki sevgilinin dışarıdaki yaşamı seyretmesine olanak tanır, hem de pencere camının ayna gibi yansıtma özelliği olduğundan, aynı zamanda iki sevgilinin narsistik biçimde kendilerini, kendi aşı görüntülerini izleyebilmelerini sağlar. Onların aşkı böylece dış-uzamda onları seyreden, hakikat'in karşıtı olan “karanlık”la yaşamaya alışkın olan insanlara, - üstelik pencere kenarları içinde bir tablo gibi çerçevelenmiş olarak (!) - karanlığı alt eden aşkın portresini sunan bir örnek oluşturur. Zaman'ı aşk'la “kabuklarından soyup" Celan, 1998, s. 58) doğurtarak yeniden yaratan aşıklar, pencerede oluşan aşk tablosunda tanrısallaşır adeta.

Şiirin başında yaban bir varlık olarak imgeselleştirdiği - bu "karanlık" - zaman'ı sevgilisiyle birlikte ehlileştirip eğiten lirik ben, son altı dizesini tümüyle "zaman” kavramına ayırır:

"Zamanı geldi, bilinmesinin!

Zamanı geldi, taşın çiçeklenmeye alışmasının,

Huzursuzlukta bir yüreğin çarpmasının.

Zamanı geldi, zamanın gelmesinin.

Zaman geldi” (Celan, 2005, s. 129).

Başkaları tarafından bilinmeyen bir şeyin açıklanmasının, bu konunun onlara da bildirilmesinin zamanının geldiğini ifade eden yukarıdaki ilk dize (7), şiirin bütünlüğü göz önüne alındığında, kapalı / mahrem alandaki aşıkların aşkının dışarıdaki, kamusal alandaki insanlara, topluma duyurulmasının zamanının geldiğinden söz edildiği izlenimini uyandırır. "(T) aşın çiçeklenmeye alışmasın(dan)"; yani bir tür mucize gibi, gerçekleşmesi çok zor olan bir şeyin gerçekleşmesini imler ki, bu da birbirlerini “afyon ve hafıza gibi” seven aşıkların zorlu aşkına uymaktadır.

\section{III- Corona'ya dair bir arasöz}

Şimdi şiirin başlığı olan "Corona”yı, sözcüğün etimolojisi ve farklı semantik açılımlarıyla aydınlatmaya çalışalım: "Corona” (Corona / die Korona) sözcügünün kökeni Latince'de "çelenk", "taç” ("Kranz", "Krone”) anlamına gelen corona sözcüğüne ve Yunanca'da da "halka" ve "yüzük" ("Ring”) anlamına gelen korônē sözcüklerine dayanır. Antik Roma'da devlet törenlerinde, ayinlerde, spor ya da sanat etkinliklerinde takılan taçlar, bir tür onurlandırma anlamına 
geliyor, kutsal bir nitelik taşıyordu. Devlet ve din adamlarına, askerlere, sanatçılara, özellikle de şairlere ve sporculara güç, yetenek ve zaferlerinin simgesi olarak çiçeklerden ya da defne ve meşe yapraklarından yapılmış taçlar takılırdı. Önceleri bir vatandaşın yaşamını kurtaran kişilere takılan corona vivica, sonradan yalnızca imparatorlara layık görülmüştür.

"Corona” sözcüğü insanlık tarihinde oldukça farklı kılıklarda karşımıza çıkar: Hıristiyanlığın ilk dönemlerinde yaşayıp şehit olmuş Damaskuslu bir azizenin adı olan "Corona", aynı zamanda ABD’nin Kaliforniya eyaletinde “dünyanın limon başkenti” olarak tanınan bir kentin adıdır. 1930’da Hoffmansthal ve Rilke gibi şairlerin metinlerinin yayımlandığı Münih ve Zürih merkezli iki ayda bir çıkan bir yazın dergisinin adı olan "Corona”; 1957'de Japon araba firması Toyota'nın ürettiği özel bir limuzin serisinin, Meksika' da üretilen bir bira markasının ve "Minutemen" adlı Kaliforniyalı bir hardcore-punk grubun şarkısının (1984) adı olarak karşımıza çıkar (sueddeutsche.de, 2020; Fischer, 2020).

Şimdi “Corona” / "Korona”nın sözlük anlamlarına bakalım: Büyük Lügat’te "1.(Zuhörerkreis man.) konferansta (vaizde, nutukta) dinleyiciler; bir işe, gezintiye, ilh. iştirak edenler. 2. güneşin etrafındaki beyaz şualar halesi" (Denker\&Davran, 1947, s. 420) olarak tanımlanır. Das Moderne Hand-Lexikon'daki “Korona" tanımı da bununla aynıdır: [1. "Kranz"], 1- Kreis, Tafelrunde (Gesellschaft); 2- heller Strahlenkranz u. d. Sonne, äußerster Teil d. Sonnenatmosphäre aus hochionisierten Gasen u. Wasserstoff, hohe Temperatur; [...] (Das Moderne Hand-Lexikon, 1978, s. 463).

Wahrig'de "Korona"nın karşılığı şöyledir: "Strahlenkranz der Sonne; Glimmentladung an elektr. Hochspannungsanlagen; (umg.) Teilnehmerkreis, Zuhörerschaft, fröhliche Runde“ (Wahrig, 1991: 782). Buraya diğerlerinden farklı olarak yüksek elektrik gerilim sistemlerindeki deşarjör anlamının eklendiği gözlenir. TDK'nın Almanca-Türkçe Sözlüğü’ndeki "Korona" tanımı da "1- Güneş 1şınlarının oluşturduğu halka, taç; güneş tacı. 2-k.d. Neşeli topluluk; dostlardan oluşmuş grup (Lat.)" (Önen vd., 1993, s. 593) şeklindedir. Duden Online Sözlüğ̈̈’nde "Korona” - ki “Corona”, "Korona” sözcüğünün yan formu olarak geçer şöyle tanımlanır: "1. (bei einer totalen Sonnenfinsternis sichtbarer) Strahlenkranz der Sonne 2.a. Gruppe, Ansammlung von [jüngeren] Menschen, die gemeinsam etwas unternehmen; [fröhliche] Schar b. Gruppe randalierender o. ä. Jugendlicher; Horde" (duden.de//Korona Strahlenkranz_Gruppe, 2020). Ayrıca bu online sözlüğe [Omurgalı hayvanlardan bulaşan ve insanlarda soğuk algınlığına yol açan virüs tipi] "Virustyp, der Wirbeltiere infiziert und beim Menschen Erkältungskrankheiten auslöst” (duden.de/ Coronavirus, 2020) şeklinde tanımlanan “Coronavirus" ve [ilk kez 2019'da insanda görülen, SARS-CoV-2 adı verilen Corona virüsün neden olduğu akciğer hastalığı] "durch das Coronavirus SARS-CoV-2 verursachte Lungenerkrankung, die erstmals 2019 bei Menschen identifiziert wurde" (duden.de/Covid_19, 2020) diye tanımlanan “Covid-19” sözcükleri yeni eklenmiştir.

Görüldüğü gibi, Almanca sözlüklerdeki üç tanım da Türkçe sözlüklerdeki tanımlarla örtüşmektedir. Ancak 1947'lerden 1990'lara dek bu sözcüğün sözlük anlamı benzer olup 2020 yılında tanımı bunlardan farklı olarak doğrudan Covid-19 pandemisiyle ilişkili olarak yapıldığı dikkat çekmektedir. İlk Corona virüsü 1960'ların ortasında görülmüş ve elektron mikroskobu altında bakıldığı zaman yüzey görüntüsü bir taca ya da çelenge benzediği 
için 1968'den itibaren virüs, "Corona" diye adlandırılmaya başlamıştır (Sauer, 2020; Şeker vd., 2020, s. 22-26). Günümüzdeki en yeni “Corona” tanımı; Giriş’te de açıkladığımız gibi, 2019'un sonunda Çin'de ortaya çıkıp tüm dünyaya yayılan ölümcül bir virüsün adı şeklinde yapılmaktadır. "SARS-CoV-2" adı verilen yeni tip korona virüsün yol açtığı enfeksiyona da “Covid 19” denilmektedir (Vuichard vd. 2020, s. 175).

\section{IV- "Corona" ve Corona}

Sözcüğün etimolojisi hakkındaki bu kısa araştırmadan sonra ortaya çıkan sonuç; metnin dışına (werkextern) yönelmeden bu tanımlardan hangisinin, ne bağlamda ve hangi açıdan Celan'ın “Corona"sına karşılık geldiğine dair tatmin edici bir açıklama yapmanın pek mümkün olmayışıdır.

Şiirin kaleme alındığı tarih olan 1948, toplama kampından sağ kurtulan Celan’ın Viyana'da yaşadığı yıllara denk düşer. Yaşamöyküsünde değindiğimiz gibi Paul Celan burada, şairlik kariyeri ve özel yaşamı açısından çok belirleyici olan önemli sanatçı, şair ve yazarlarla tanışır. Ki bu şairlerden birisi, büyük bir aşk yaşadığı Ingeborg Bachmann’dır. Mayıs 1948'de Bachmann, ailesine yazdığı mektupta yeni tanıştığı "gerçeküstücü şair Paul Celan'ın" kendisine ilan-ı aşk ettiğini, odasını "gelincik tarlasına" çevirdiğini, bir ay sonra Celan'ın, 22. yaş gününde (25.06.1948) gelip kendisini hediyelere boğduğunu ve akşamı şarap içip yemek yiyerek birlikte geçirdiklerini anlatır (8) (Aktaran: Rychlo, 2012, s. 10). İşte Celan'ın 1948'de yazdığı “Corona” adlı bu şiiri de, Ingeborg Bachmann'la yaşadığı fırtınalı aşkın ilk zamanlarından izler taşır (9). Nitekim çalışmada yararlanılan yazara dönük kuramlardan olan biyografik eleştiri yöntemine göre; "(y)azarın hayatında yer alan olaylar, içinde yaşadığı koşullar, aile ortamı, okuduğu kitaplar, başından geçen aşklar, v.b., bütün bunlar yazarın kişiliğinin ve dolayısıyla eserlerinin iyi anlaşılması için gerekli şeyler sayılır” (Moran, 1994, s. 118).

Çözümlememizde göstermeye çalıştığımız gibi, şiirde tutkulu bir aşk yaşayan bir çift vardır: Art arda gelen metaforlarda kullanılan yoğun cinsel simgeciliğin de ortaya koyduğu gibi, kapalı bir uzamda aşklarını dolu dolu, tutkulu bir cinsellikle yaşayan bu çift, aynı zamanda "karanlık" ("Dunkles") hakkında konuşmaktadırlar. Şiirin ikinci kıtasındaki "ağızlar doğruyu söylemekte" (Celan, 1998, s. 58) dizesi de, iki aşığın karanlık gerçekleri de çırçıplak soyduğunu, hakikat'i konuştuğunu imler. Nitekim Celan 1948'de bu şiirine "wir sagen uns Dunkles" (Celan, 1983, s. 37) diye yazarken, Bachmann'ın da 1953'te "Dunkles zu sagen" ["Karanlığ1 Söylemek"] (Bachmann, 2003, s. 42) başlıklı bir şiir yazması, iki şair arasındaki aşkın poetikalarına nasıl yansıdığının bir başka göstergesidir.

“Corona”daki aşıkların yalnızca birbirlerini sevip sevişmekle kalmayıp, birbirlerine "karanlık”ı söyleyip anlatmaları, yani "karanlık" üzerine düşünüp tartışmaları; ilişkilerinin yalnız tensel boyutta kalmayıp düşünsel bir derinliği de olduğunu ortaya koyar. Nitekim Celan, Bachmann'a yazdığı bir mektupta (31.11.1957) ondan vazgeçememesinin nedenini şöyle açıklar: "Du weißt auch: Du warst, als ich Dir begegnete, beides für mich: das Sinnliche und das Geistige" [Sen de biliyorsun: Seninle karşılaştığım ilk andan beri her ikisi de geçerliydi 
benim için: Cinsellik ve tinsellik] (Aktaran: Rychlo, 2012, s. 14). Bu veri, aynı zamanda her iki figürün de sözcüklerle, söz sanatıyla yakın bir ilişkileri olduğunu ele verir ki, ikisi de dünya çapında ün kazanmış büyük şairlerdir.

"Karanlık" metaforu, bir iç-uzamda bulunan aşıkların "pencere"den izle(n)dikleri “cadde"deki / dış-uzamdaki / toplumdaki kötülük sorununu imler. Şiirin yazıldığı 1948 yılı, II. Dünya Savaşı'nın bitiminden üç yıl sonrasıdır. Celan'ın yaşamöyküsü göz önüne alındığında; "Corona"daki bu "karanlığın" imlediği - gerçek dünyadaki - kötülüğün; aralarında çok sevdiği annesinin ve babasının da bulunduğu altı milyona yakın Museviyi katleden Nazi Almanyası'na karşılık geldiğini çıkarsamak hiç de güç değildir. Celan'dan bir yıl öncesinde de Albert Camus (1913-1960) La Peste (Veba) adlı romanında, Cezayir'in Oran kentinde milyonlarca insanın ölümüne neden olan veba salgınını anlatırken, Fransa’yı işgal eden Nazi ordularını "kara veba" alegorisiyle canlandırmıştır ([1947], 1985). Bu bakımdan Celan'ın üstelik şairin Fransız yazınını yakından takip ettiği de bilinir - "karanlık" (1948) metaforuyla Camus'nun “kara veba” (1947) analojisinin, dünyadaki aynı ölümcül virüse göndermede bulunma noktasında örtüştüğü savlanabilir.

Şiirdeki âşıkların birbirlerini "afyon ve hafıza gibi” ("Mohn und Gedächtnis") (Celan, 1983, s. 37) sevmesi, unutmanın metaforu olan afyonla, anımsamaya yarayan belleğin bu aşk'ta iç içe geçmesi, yine gerçeklik düzleminde Celan ve Bachmann aşkındaki iç çatışkının bir yansıması olarak okunmaya açıktır: Bir Nazi subayının kızıyla, ebeveynleri Nazi toplama kampında öldürülen bir savaş esirinin aşkı en baştan mutsuzluğa mahkumdur. Nitekim ailesi toplama kamplarında öldürülen Musevi Celan'la, 1932'de Nasyonal Sosyalist harekete kat1lan bir ilkokul müdürünün kızı olan Bachmann'ın aralarında siyasal, ulusal ve dinsel bağlamda “aşılamaz karşıtlıklar” olduğuna dikkat çeken Rychlo da iki şairin tüm bu olumsuzlukların karşısına "insan varoluşunun en yüce ahlak yasası olarak aşkı" koyduklarını, ancak bununla başa çıkamayacaklarının baştan belli olduğunu savlar (Rychlo, 2012, s. 10).

Şimdi tarihsel, pozitivist, (psiko)biyografik eleştiri ve yorumbilgisi doğrultusunda elde ettiğimiz bu verilerin ışı̆̆ında, şiirin başlığının niçin "Corona” olduğunu bir kere daha sorgulayalım: Kısa araştırmamızın ortaya koyduğu gibi, “Corona”yı henüz adını pandemik virüse vermediği zamanlarda kaleme alan ve burada Bachmann'la aşkını imgeselleştiren Celan, bu başlığı en çok, sözcüğün etimolojik kökenindeki “taç” anlamından dolayı kullanmış olabilir. Özellikle şiirin; kapalı bir alandaki aşıkların aşkının kamusal alandaki insanlara, yani topluma duyurulmasının zamanının geldiğinin yineleyimsel olarak anlatıldığı son kıtası bu bağlantıyı berkiten en güçlü veridir. Burada açıkça sevdiğine ilan-ı aşk eden lirik ben, bunu herkese ilan etmenin "Zamanı geldi, bilinmesinin!" diyerek onunla evlenmek istediğini haykırır: bu tutkulu aşkı, artık evlilikle taçlandırmaya "Zaman gel(miştir)" (Celan, 2005, s. 129).

Nitekim yazısında "Corona bir gelin tacı mıdı?" diye soran Sauer, şiirinin son dizelerinde sabırsızlıkla "zamanı geldi” diye haykıran Celan'ın bu başlıkla aslında Ingeborg Bachmann'la evlenmek istediğini ima ettiğini savlıyor (Sauer, 2020). Yine bir başka yazıda Celan'ın, Bachmann'la aşk ve nefretin iç içe girdiği (amor fou) ilişkilerinin daha ilk başladığı zamanlarda kaleme aldığı bu şiirinde, Bachmann'ın başını imgesel bir gelin tacıyla süslemek istediği, yani onunla evlenme arzusunu yansıttığı belirtiliyor (wienerzeitung.at, 2020). 
Peter Rychlo da, Celan'ın 1948 yılının ilk yarısında, Viyana'da kaldığı süre içinde yazdığı şiirlerinde, özellikle de aşk ve ölümü tematize ettiği Latince "taç" anlamına gelen Corona başlıklı bu şiirinde aslında Bachmann'la yaşadığı aşkı anlattığını öte yandan "çok bariz erotik unsurlar"1n yanında bu şiirin, "ahlaksal ve zamana özgü sorunlara" dikkat çektiği savliyor (Rychlo, 2012: 11). Beate Sommerfeld de Celan ve Bachmann arasındaki aşkın izlerini taşıyan "Corona" adlı bu şiirde, iki şairin de geçmişinden dolayı unutulmasına olanak olmayan Holocaust bağlantısına dikkat çekerek, şiirden yaptığı bir alıntıyla her şeye rağmen sonuçta elde kalan birbirini "afyon ve bellek gibi” sevmektir, diyor:

Gerade bei Texten wie Corona, in dem Celan die Beziehung zu Bachmann aufarbeitet, wird der Holocaustbezug gerne gegen eine - vielleicht für den Leser gefälligere - Lektüremöglichkeit als Bachmann gewidmetes Liebesgedicht ausgespielt. In Celans Texten wird beides jedoch zusammengedacht Celans Begegnungen mit einem Du stehen damit unter dem Zeichen des ,20. Jänner", das Artikulieren von Emotionen ist ohne den dialogischen Bezug auf die verdrängte / vergessene Vergangenheit nicht denkbar: Lieben kann man einander nur ,wie Mohn und Gedächtnis (Sommerfeld, 2014, s. 150).

\section{Sonuç}

Bu çalışmada, dünyanın her yerine yayılarak sayısız can alan ve (ölümü unuttuğumuz) yaşamlarımızda her anlamda kökten değişimler yaratan pandemik virüsün adı olan "Corona" ile bu virüsün ortaya çıktığı 2020 yılında, ölümünün 50. yılına girdiğimiz Paul Celan'ın aynı başlığ taşıyan şiirinin ilişki-si(zliği)ni tartıştık. İlginç rastlantılardan yola çıkarak, hem usta şair Paul Celan'ın şiirine, hem de tüm insanlığı tehdit eden Corona virüs salgınına dikkat çekmek amacıyla kaleme aldığımız bu çalışmada, metiniçi (werkimmanent) ve metindışı (werkextern) eleştiri yöntemlerini dengeli biçimde harmanlayan eklektik bir yöntem kullandık.

Çalışmada ilk olarak Paul Celan'ın yaşamına ve poetikasına değindik, sonra metin içi eleştiri yöntemi 1şığında "Corona" adlı şiirini çözümledik. Ardından "Corona” sözcüğünün etimolojisini araştırdık ve bu kez de yazarın kişisel tarihine ve dönemin tarihsel art alanına yönelen biyografik, tarihsel pozitivist eleştiri ve yorumbilgisi gibi metindışı eleştiri yöntemleriyle, Celan’ın "Corona” adlı şiirinin esasında aynı adlı pandemik virüsle ilişkisi olmayıp Bachmann'la yaşadığı büyük aşkla bağlantılı olduğunu ortaya çıkardık.

Saptamamıza göre bu şiir herşeyden önce bir aşk şiiridir: ebeveynleri Nazi toplama kampında öldürülen, esir düştüğü kamptan sağ olarak kurtulan ama yaşamayı hazmedemeyip Seine'nin serin sularında ölmeyi seçen Celan ile bir Nazi subayının kızı olan ve Celan'dan üç yıl sonra (uyku ilacı aldığı bir gece elindeki sigaranın yol açtığı bir yangında öldüğü söylense de) onun gibi intiharla çekip giden Avusturyalı şair Ingeborg Bachmann'la yaşadığı tutkulu, trajik ve hazin aşk'ın ilk evresine tanıklık eden bir şiiridir. Etimolojik olarak Latince'de "taç", "çelenk" anlamına gelen "Corona" adı, milyonlarca insanın canını alan virüse taca benzerliğinden ötürü verilmişken, Celan'ın şiirine adını, sevdiğini gelin tacıyla taçlandırmak, onunla evlenmek isteyen lirik ben'in ilan-ı aşkından dolayı vermiştir. 
Ancak bu şiir katışıksız bir aşk şiiri olmayıp art alanında güçlü bir çağ eleştirisi düzlemi barındırır: Yaptığımız çözümlemede Celan ve Bachmann'ın izdüşümü olarak şiirdeki "biz” i oluşturan aşıkların üzerine tartışıp konuştuğu "karanlık" ("Dunkles”) metaforunun en çok, dünyadaki başka bir ölümcül virüse, Celan'ın ebeveynlerini kurban verdiği Nazizme karşılık geldiğini saptadık. Celan'ın II. Dünya Savaşı döneminin Nazi Almanyası'ndaki “karanlık”a örtük göndermeler yaptığı “Corona” şiiriyle, II. Dünya Savaşı'ndan beri dünyada ilk kez bu kadar çok can kaybının yaşanmasına yol açan Corona adlı pandeminin öldürme kapasitesi bağlamında birbirleriyle örtüştüğü savlanabilir. Çalışmamızda saptadığımız gibi, dışuzamda onları seyreden, hakikat'ten uzakta, "karanlık”la, "karanlık”ta yaşayan insanlara, o "karanlık"1 alt eden tanrısallaşmış bir aşkın portresini sunan bu çiftin aşkı aynı zamanda bir başkaldırı niteliği taşır. Şiirin başında zaman'ı yeniden yaratıp sonunda 'aşk zamanı' ilan eden bu aşk, yalnızca Nazizme / Holocaust'a başkaldırmakla yetinmez, iki büyük dünya savaşı ve sıcak savaşın hemen ardından gelen soğuk savaş dönemiyle tam bir savaş yüzyılı olan 20. yüzyıla egemen "karanlık”a karşı bir protestoya dönüşür.

Sonuç olarak Paul Celan'ın 1948'de kaleme aldığ 1 "Corona” adlı şiirin, çağın vebası olarak dünya üzerinde çok sayıda insanın ölümüne neden olan "Corona” adlı pandemik virüsle bir ilişkisi yoktur. İçinde bulunduğumuz 2020 yılında en ölümcül haliyle karşımıza çıka(rıla) n Corona'nın, yine bu yıl içinde ölümünün 50. yılına girdiğimiz Celan'ın bir şiirinin başlığını taşıması, bu çalışmada ortaya koyduğumuz gibi, yalnızca incelemeye değer ilginç bir rastlantıdan ibarettir.

\section{Notlar}

1 Hatta Ingeborg Bachmann'ın da Celan'ın "Corona” adlı şiirine karşılık olarak "Die gestundete Zeit" (1953) adlı şiirini yazdığı bilinir (Bazarkaya, 2018, s. 439). Bazarkaya Celan'ın lirik ben'inin "Corona”da sevdiğine olan aşkını herkese duyurmak isterken, Bachmann'ın bu şiirinde tersine ayrılmak üzere olan bir kadın ve erkeği betimlediğine dikkat çeker: "[...]: bei Celan mag es den Schritt des heimlichen Corona-Paares bezeichnen, sich öffentlich zu seiner Liebe zu bekennen (,es ist Zeit, daß man weiß!“), wohingegen bei Bachmann damit wohl die bevorstehende Trennung von Mann und Frau angesprochen ist - ein Detail, das man als bewusste oder unbewusste Anspielung der Autorin auf ihre zurückliegende Emanzipation von Perkonig deuten könnte" (a.g.e., s. 449).

2 Bu şiirden yapılan Türkçe alıntılar, aktarımın gücüne göre yer yer Ahmet Cemal'in, yer yer de Oruç Aruoba'nın çevirilerinden aktarılmıştır.

3 Celan'ın sonbahar metaforuyla ölümü "dost” gördüğünü imlediği bu noktada, Avusturyalı şair Rainer M. Rilke'nin (1875-1926) ünlü Duineser Elegien (Duino Ağıtları) ile metinlerarası bir diyaloğa girdiği gözlenir: "Ben, adsız, seni seçtim kendime, çok uzaktan/ Her zaman haklıydın sen, senin kutsal buluşundur/ dostumuz ölüm” (Rilke, 1993, s. 70). Aslında bir sonbahar betimiyle başlayıp şirinin son kıtalarında yineleyimsel olarak "Es ist Zeit" ifadesini kullanması açısından da Celan’ın bu şiiri, Rilke'nin "Herr: es ist Zeit" şeklinde başlayan "Herbsttag" adlı sonbahar şiirini anıştırır (Rilke, 1973, s. 37-38).

4 Nitekim Kimmerle bu şiirin "(y)eni ve kültürlerarası olarak zenginleştirilmiş bir zaman anlayışı" geliştirme konusundaki düşüncelerinde kendisine "yol gösterici" olduğunu belirtir. Ona göre "( $t$ )aşların çiçeklenmesi" vb. metaforik anlatımlarla yüklü olan bu şiirde "yanlış bir zaman anlayışının hüküm sürdügü ve uygun zaman anlayışının paradoksal anlatımlarla kavranmaya çalışıldığı açıklık kazanır” (Kimmerle, 2014, s. 67).

5 Nitekim Cevizci’nin açımladığı gibi, “(b)elleğin oluşumunda ya da anımsama sürecinde, üç ayrı evre söz konusu olur: I-Daha önce algılanmış olan nesnenin zihinde canlandırılması, bellekte bir imge oluşturulması, IIimgenin, anımsayanın geçmişinin bir parçasını meydana getiren bir nesnenin imgesi, sureti olarak tanınması ve III- anımsanan nesnenin psikolojik ya da fiziki bir zaman çerçevesi içine yerleştirilmesi” (Cevizci, 1999, s. 111). 
6 "İstiridyelerin ve deniz kabuklarının sulardan kaynaklanmaları ve ay simgeciliklerinden daha çok dişilik organıyla olan benzerlikleri onların sihirsel güçlerine olan inancın yayılmasına katkıda bulunmuş olmalıdırlar. Zaten bazı çift kapaklı deniz kabuklarını ifade eden terimler bu benzetmeyi açık etmektedirler: örneğin eski Dâncada istiridye kıldefish kelimesiyle karşılanmaktadır (kude: dişilik organı, ...). Deniz kabuğu ile kadın üreme organı arasında benzerlik kurulması Japonya'da da görülmüştür (Eliade, 1992, s. 146-147).

7 Cemal'in çevirisi de şöyledir: "zamanı geldi artık bilmelerinin! / Taşların çiçeklenmesinin, / Bir yüreğin tedirgin atmasının zamanı geldi. / Zamanıdır artık zamanı gelmesinin. / Zamanı geldi” (Celan, 1998, s. 58).

8 Rychlo bu mektupları 2008'de yayımlanan "Herzzeit” [Kalp Zamanı] başlıklı şu kitaptan aktarmıştır: Herzzeit. Ingeborg Bachmann - Paul Celan - Der Briefwechsel. Mit den Briefwechseln zwischen Paul Celan und Max Frisch sowie Ingeborg Bachmann und Gisèle Celan-Lestrange. Hg. Bertrand Badiou, Hans Höller, Andrea Stoll und Barbara Wiedemann. Frankfurt a. M.: Suhrkamp.

9 Çünkü birlikte yaşayamayan ancak birbirlerinden de kopamayan iki şairin aşkı, Celan'ın evliliğinden sonra da devam eder. Hatta Celan'ın eşi, Bachmann'ın eşine duyduğu aşka saygı duyar (Rychlo, 2012, s. 14).

\section{Kaynaklar}

Bachmann, I. (2003). Saemtliche gedichte. München-Zürich: Piper.

Bazarkaya, O. K. (2018). Ingeborg Bachmanns Die gestundete Zeit im Lichte von Paul Celans Todesfuge und Corona. Atatürk Üni. Sosyal Bilimler Enstitüsü Dergisi. Nisan 201822 (Özel Say1), 437-455.

Boccacio, G. (2018). Decameron. R. Teksoy (Çev.) İstanbul: İnkılap.

Camus, A. (1985). Veba. N. Önol (Çev). İstanbul: Altın Kitaplar.

Celan, P. (1983). Corona (Mohn und Gedächtnis). Gesammelte Werke in fünf Bänden, Gedichte I., Beda Alleman, Stefan Reichert (Hg.). Frankfurt a.M.: Suhrkamp, S. 37.

Celan, P. (1998). Bütün şiirlerinden seçmeler. A. Cemal (Çev.) İstanbul: Kavram.

Celan, P. (2005). Neredeyse yaşayacaktın. O. Aruoba (Çev.) İstanbul: Dünya.

Cevizci, A. (1999). Felsefe sözlüğ̈̈. İstanbul: Paradigma.

Denker, A.C. \& Davran, B. (1947). Büyük Lügat. Grosses Deutsch-Türkisches Wörterbuch, Cilt: II, $B d$. II (E-M). İstanbul: Kanaat.

Das Moderne Hand-Lexikon. Wissen von A-Z. (1978). Stuttgart. Hamburg. München: Knaur.

Emer Kızıler, F. (2014). Duino ağıtları (Rainer M. Rilke) ile bir meleğin yakarışı/ dualar (Hertha Kraeftner) adl yapttlarda melek imgesi. Konya: Çizgi.

Fischer, M. (2020). Neunzig Jahre "Corona”. Zum Jubiläum einer Zeitschrift in dunklen Zeiten”, (08.05.2020), https://adz.ro/artikel/artikel/neunzig-jahre-corona (Erişim Tarihi: 09.05.2020, 00: 20: 38).

Güntekin, R. N. (2010). Salgın \& madalyonun ters tarafi. İstanbul: İnkılap.

Hiebel, H. (2006). Hermetische Lyrik: Paul Celan, Das Spektrum der modernen Poesie: Interpretationen deutschsprachiger Lyrik um 1900-2000 im internationalen Kontext der Moderne, Teil II: 1945-2000. (s. 255- 307). Würzburg: Königshausen\&Neumann.

https://tr.euronews.com/2020/05/14/dso-ye-gore-covid-19-bir-epidemik-peki-pandemik-ileepidemik-arasindaki-fark-ne (Erişim Tarihi: 12.05.2020, 04: 30: 24). 
https://www.duden.de/rechtschreibung/Korona_Strahlenkranz_Gruppe (Erişim Tarihi: 05.05.2020, 17: 02: 43).

https://www.duden.de/rechtschreibung/Coronavirus (Erişim Tarihi: 06.05.2020, 10: 59: 50).

https://www.duden.de/rechtschreibung/Covid_19 (Erişim Tarihi: 31.03.2020, 00: 20: 00).

Kızıler, F. (2006). Moderniteden postmoderniteye kavramsal bir yolculuk. Patrick Süskind'in Parfüm adlı romanında postmodernist açılımlar. Erzurum: Salkımsöğüt.

Kimmerle, H. (2014). Kültürlerarası felsefe açısından Hegel. A.Çırakoğlu (Çev.) İstanbul: Gündoğan.

Mann, T. (1993). Der Tod in Venedig und Andere Erzaehlungen. Frankfurt a.M.: Fischer.

Maren-Grisebach, M. (1972). Methoden der Literaturwissenschaft. München: Francke.

Marquez, G. G. (2019). Kolera günlerinde aşk. Ş. Karadeniz (Çev.) İstanbul: Can.

Moran, B. (1994). Edebiyat kuramlart ve eleştiri. İstanbul: Cem.

Rilke, R. M. (1993). Duino ă̆ıtları. C. Alkor (Çev.) İstanbul: İyi Şeyler.

Rilke, R. M. (1973). Buch der Bilder. Frankfurt am Main: Insel.

Rychlo, P. (2012). Sie Sagten Helles und Dunkles. Paul Celan und Ingeborg Bachmann als Liebespaar, Der literarische Zaunkönig. Nr. 1/ 2012, 10-16.

Sauer, B. (2020). "Corona“ - von Paul Celan" https://www.rainews.it/tgr/tagesschau/articoli/2020/04/tag-paul-celan-lyrik-corona-bene-sauer-petr-20042020-252e703d-5ad4-4af9acca-23db12dd64b3.html

Schimmel, A. (1998). Sayıların gizemi. M. Küpüşoğlu (Çev.) İstanbul: Kabalc1.

Schnitzler, A. (1992). Das Sterben. Erzaehlungen. Frankfurt am Main: Fischer.

Sommerfeld, B. (2014). Wenn ich die Karrenspur fräße ... - Zur Artikulation von Gefühlen in meineidiger Sprache in einigen Gedichten Paul Celans, (s. 141-167). Bonn: Convivium. Germanistisches Jahrbuch Polen.

Sparr, T. (1997). Metaphorische Gedankenstriche zwischen Ingeborg Bachmann und Paul Celan, Poetische Korrespondenzen. Vierzehn Beitraege. Bernhard, Böschenstein\& Sigrid, Weigel. (s. 176-188). Frankfurt a. M.: Suhrkamp.

Sparr, T. (2012). Paul Celan, Metzler Lexikon der deutsch-jüdischen Literatur, Andreas B. Kilcher (Hg.). (s. 104-107). Stuttgart. Weimar: J.B.Metzler.

Sparr, T. (2020). Todesfuge. Biographie eines Gedichts. Stuttgart: Deutsche Verlags-Anstalt.

Şeker, M.\& Özer, A. \&Tosun, Z. \&Korkut, C. \&Doğrul, M. (2020). Covid-19 pandemi değerlendirme raporu. (TÜBA raporları no: 34). Ankara: Türkiye Bilimler Akademisi.

Todorov, T. (2001). Poetikaya giriş. K. Şahin (Çev.) İstanbul: Metis.

Toprak, M. (2016). Hermeneutik (yorum bilgisi) ve edebiyat. İstanbul: Dergâh.

Vuichard, D.\&Widmer, A.\&Krause, M. (2020): Eine Epidemie mit einer neuen Dimension. Ein neues Coronavirus breitet sich aus: machen wir es richtig?", Swiss Med Forum. 2020: 20 (1112), 175-177.

Önen, Y.\&Şanbey, CZ. \&Ülkü, V. (Haz.) (1993): Almanca-Türkçe sözlük. Ankara: TDK. Wahrig. Deutsches Wörterbuch (1991). Gütersloh. München: Bertelsmann Lexikon. 


\section{Elektronik kaynaklar}

“Corona, Celan und die Bachmann”, https://www.wienerzeitung.at/nachrichten/kultur/ literatur/2057366-Corona-Celan-und-die-Bachmann.html (Erişim Tarihi: 14.04.2020, $16: 30)$.

"Corona-Lexikon: Das Wort, das seine Unschuld verlor", https://www.sueddeutsche.de/kultur/ corona-andere-bedeutung-1.4853423 (Erişim Tarihi: 24.03.2020, 22: 13). 